\title{
ADDITIONS TO THE BIRDS OF ASSINIBOINE PARK, WINNIPEG, MANITOBA
}

MARTIN K. MCNICHOLL, Long Point Bird Observatory, P.O. Box 160, Port Rowan, Ontario. NOE $1 \mathrm{MO}$

When I first started to watch birds seriously, one of my favourite winter outings was a trip by bus to Assiniboine Park in Winnipeg, Manitoba, usually meeting my aunt Gertrude McNicholl, en route. Later, during my high school days, I enjoyed Saturday morning bird identification classes conducted by the Natural History Society of Manitoba (now known as the Manitoba Naturalists Society). For these reasons, I was especially delighted to learn that a checklist of the park and nearby Assiniboine Forest had been published. ${ }^{1}$ In general, this list appears to be thorough, with several rarities seen during our bird classes included. However, a review of my notes showed three species not on the published list, and one seasonal extension that can be made.

\section{White-winged Scoter}

During one of the NHSM bird walks, the party led by veteran Winnipeg birder, Gordon Smith, spotted a male White-winged Scoter on the Assiniboine River where it flows through the park. In addition to Smith and I, my notes indicate that it was seen by Ken Johanneson, John Rudd, and "others."

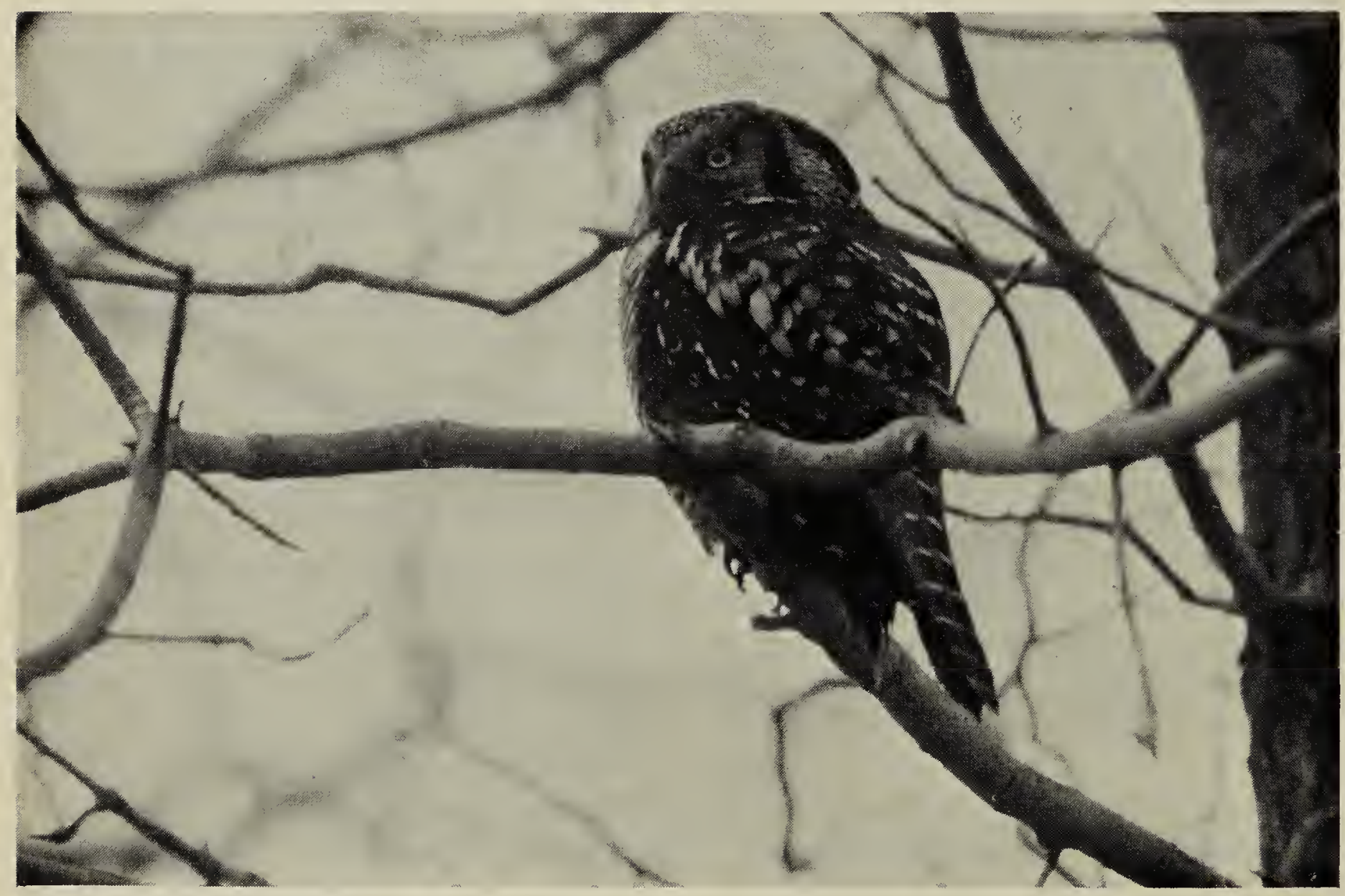

Hawk Owl

Wayne Lynch 


\section{Northern Hawk-Owl}

In November 1962 my father, the late Archie McNicholl, returned from work one day to say he had seen an unusual owl in Assiniboine Park. At that time, he taught school in Charleswood and the park was on his favourite route between school and our Valour Road home. He tentatively identified the bird from my field guides as a Northern Hawk-Owl, and another check the next day convinced him. Although he would not consider himself an active birder, he enjoyed taking my anunt and I on bird outings until I was old enough to drive, and thereafter still came along frequently. Consequently he was familiar with most common species. My neighbour, Ken Johanneson and I saw the bird on 24 November and again on 2 January 1963, when we showed it to the late Dr. Harold Popham. My father saw it frequently that winter, and Mossop mentions that it was seen by several people during the Christmas bird count that year, and records an observation on an unstated date by E. Bendit. ${ }^{2}$ This is the bird that Smith mentions as present in "west Winnipeg" from 14 November to 23 February, as one of 10 records of the species in Manitoba that winter. ${ }^{5}$

\section{Black-backed Woodpecker}

The checklist includes the Black-backed Woodpecker as irregular in fall. A female observed by Byron Paulson, Jr. and I near the duck pond on 5 January 1963 adds winter to this species' occurrence.

\section{Boreal Chickadee}

The most surprising omission from the list is Boreal Chickadee, as the cedars near the English Gardens and the feeders of Superintendent Hector MacDonald were generally stated as the place to look for these birds in Winnipeg by the birding fraternity during my formative years. I recall various frustrating attempts to find them there after various friends and relatives had seen them a few days or hours earlier. I finally did see them with David Hatch, Andy Heidrick, Harold Hosford, and the late Perry Silverman on 16 November 1963. Ken Johanneson and I saw one on 1 March 1964 and two or three on 29 March. Mossop mentioned seeing them near the duck pond on 6 December 1963, a winter when MacDonald had mentioned them as regularly around. ${ }^{3}$ In 1966, he mentioned that there had been no recent reports there after being regular "each winter" at MacDonald's feeder. ${ }^{4}$ This was slightly before any of the three compilers of the checklist were active in the province, probably explaining why they were not aware of the former status of this chickadee in the park. Their disappearance coincided rather closely with MacDonald's retirement, after which the feeders were not maintained, at least for the next few winters

No doubt this very accessible and productive park will remain a favourite of Winnipeg birders for many years, and additional species can be expected. Holland, Koes and Krieger have done local and visiting observers a real service in compiling the list. ${ }^{1}$

1 HOLLAND, G.E., R.F. KOES and K.G. KRIEGER n.d.(1983) Field Checklist of the birds of Assiniboine Park and Assiniboine Forest. Winnipeg Parks and Recreation Dept., Winnipeg.

${ }^{2}$ MOSSOP, H. 1963 Hawk Owl in Assiniboine Park. Chickadee Notes No. 420 Winnipeg Free Press, 2 February 1963.

3 MOSSOP, H. 1963 The Boreal Chickadee. Chickadee Notes No. 465 Winnipeg Free Press 14 December 1963

${ }^{4}$ MOSSOP, H. 1966 Birds with odd colorings Chickadee Notes No. 618 Winnipeg Free Press, 5 November 1966

5 SMITH, L.B. 1963 Observers reports - Jan. 1 to March 15, 1963. Nat. Hist. Soc. Manitoba Ornithol. Sect. Newsletter No. 3:23-25 